\title{
Unfair Terms in Insurance Contracts
}

\author{
Nina Adelmann
}

Published online: 22 August 2008

OEROPEAN LAW ACADEMIE DE DROIT EUROPEEN (C) ERA 2008

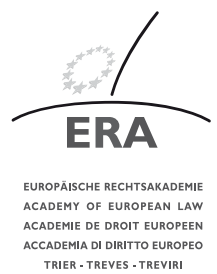

\section{Introduction}

As insurance is a "legal product", the influence of the legal environment on an insurance product is very strong. According to the rules of private international law, the law applicable to mass insurance contracts is normally the law of the state in which the policyholder has his habitual residence. As a consequence insurers must be and actually are aware of the fact that any product they sell across borders will be subjected to different law rules in different member states.

If, for example, an insurance product which is lawfully marketed in England is sold cross-border to a German customer, German law courts might submit the contract terms of the English insurer to the fairness test under $\S 307$ BGB. A particular exception contained in the contract terms which is, in principle, exempt from control under the English Unfair Terms in Consumer Contracts Regulations 1999 may be subject to control under German law and could be held to be invalid according to art. 305, 307 BGB. If so, the scope of cover of one and the same particular insurance product will turn out to be broader in Germany than in England due to the differences in the applicable law. It follows that insurers will be reluctant to provide cross border services.

To complete the internal market in insurance products, it is essential to create one insurance law applicable in each member state of the European Union and one fairness test applicable to all insurance clauses. Only if it is guaranteed that all insurance clauses will be subject to control under the same conditions, will insurers be

Nina Adelmann ( $\bowtie)$, Lecturer

University of Mannheim, International Private Law

Schloß Ehrenhof West EW 285, 68161 Mannheim Germany

e-mail: adelmann@rumms.uni-mannheim.de

This paper is the written version of the presentation given by the author at the conference European Insurance Contract Law and the Common Frame of Reference (CFR), organised by ERA and the Joint Network on European Private Law in Trier on 21-22 January 2008. 
willing to provide cross-border services, as only then will an effective risk pooling be possible. And only if a potential policyholder can be sure that he will be protected against abusive clauses in the same way in every member state, will he be willing to conclude a contract in a country that is not his own and a language that is not his mother tongue.

Therefore Art. 2:304 of the PEICL has been created.

\section{Art. 2:304 PEICL}

\subsection{Council Directive 93/13/EEC of 5 April 1993}

Art. 2:304 PEICL restates the rules contained in Article 3, 4 and 6 of Directive 93/13/ EEC of 5 April 1993 on Unfair Terms in Consumer Contracts ${ }^{1}$ as well as Art. 4:110 of the Principles of European Contract Law (PECL) and adapts them to the context of insurance law. The provision has been formulated to take into account the particularities of insurance contracts, which deal with insurance as an immaterial service. In accordance with Article 7 para. 1 of the Directive, this provision is intended to ensure that adequate and effective means exist to prevent the continued use of unfair terms in insurance contracts.

The Directive on Unfair Terms in Consumer Contracts is applicable to insurance contracts. The 19th recital explicitly says that in insurance contracts, the terms which clearly define or circumscribe the insured risk and the insurer's liability shall not be subject to such assessment since these restrictions are taken into account in calculating the premium paid by the consumer. However, this does not mean that every term that deals with the insured risk and the insurer's liability is exempted from the fairness test. While the English text of the Directive gives the impression, that every clause that defines the insured risk or the insurer's liability is taken into account in calculating the premium and thus has to be exempted from the fairness test, the German version of the Directive ("soweit") shows that an exemption only has to be made, if the clause actually has been considered in the calculation of the prime. To provide an efficient protection of the policyholder's rights, the number of clauses exempted from the fairness test must be restricted. No matter how recital 19 of the Directive is interpreted, Article 8 of the Directive allows the member states to adopt or retain the most stringent provisions compatible with the Treaty in the area covered by the Directive to ensure a maximum degree of protection for the consumer. Thus for the purpose of the PEICL, only core terms will be exempted from the fairness test.

\subsection{Scope of application}

Like Article 4:110 PECL, Art. 2: 304 PEICL extends the scope of application of Article 3 of the EC Directive 93/13/EEC on Unfair Terms in Consumer Contracts to commercial contracts. The restriction to consumer contracts is not appropriate in insurance law as policyholders need protection against insurers, whether they are

1) OJ L 95 of 21 April 1993, p. 29. 
consumers or not. Insurers commonly draft the terms of the insurance contracts in advance, so that policyholders have no opportunity to negotiate the terms.

Article 2.304 applies neither to terms that have been individually negotiated nor to "core terms". In the interests of freedom of contract and free enterprise, such terms are protected from court intervention. In a free insurance market the essential elements of any insurance contract, such as the scope of insurance cover and the premium paid, are matters for the agreement of the parties and should not be subject to intervention by the courts or the state.

As insurance contracts deal with an immaterial service, the definition of the "main subject matter of the contract" is not easy to give. As in an insurance contract both, positive descriptions of the insured risk and exclusion clauses, define the scope of insurance cover, an effective protection of the policyholder can only be achieved, if the exclusion of "core terms" is limited to a restricted part of clauses. So in Paragraph $3 \mathrm{~b}$ of Art. 2:304 PEICL the exception of core terms from the appliance of this article has been limited to terms that state the essential description of the cover granted or the premium agreed.

In this context, terms that give the essential description of the cover granted and/or of the premium agreed can be terms that give a crucial definition or circumscription of the type and subject of insurance, the insured risk, the insurer's liability, the insurance benefit, the sum insured, the insured interest or the insurable value.

However core terms are only exempted from the fairness test, if they are drafted in plain intelligible language. The freedom of contract can only encroach, if the policyholder had the possibility to understand the terms that are crucial for his decision to sign the contract.

Terms that have been individually negotiated are also excluded from the fairness test. The definition of an "individual negotiation" requires that the policyholder had a real opportunity to influence the formulation and the content of the terms. If this is the case and both parties, the insurer and the insured, have agreed in accepting the term as negotiated, the freedom of contract has to be respected and the term may not be submitted to legal control.

\subsection{Overall estimate}

The assessment of the unfair character of terms is supplemented by means of making an overall evaluation of the interests involved. This is done by using the tests of "good faith" and "imbalance". The expression "good faith" is taken directly from the Directive on unfair terms (Art. 3.1). A typical example of insurance conditions in conflict with "good faith" is conditions that are supposed to mislead the insurance taker about his rights and duties. Also the way of expressing the "imbalance" in the rights and obligations of the parties is taken directly from the Directive (Art. 3.1). It is not always easy to see the sharp line between these two tests. Often they overlap each other, meaning that if a term is in contradiction with "good faith" there is automatically also an "imbalance". In any case, it must be stressed that this result must always be one of the overall estimate and that article 2:304 para. 1 requires both a contrast to "good faith" and an "imbalance"; fulfilling the requirement of one of them is not enough.

To be able to answer the question if a term causes a significant imbalance, two matters have to be put on the scale: the risk and the premium. The risk covers several 
circumstances: the "factual" risk (e.g. property insurance against a certain type of damage), the legal risk (e.g. the attitude of the law concerning damage caused by the insured with gross negligence), the cost risk (besides administration costs some types of events might give rise to unwarranted claims and trials at great expense), the financial risk (the total economic development, e.g. the interest rate situation). The insurers are entitled to take into consideration all these circumstances in deciding on the premium and the terms. While the factual and the cost risk depend on circumstances regarding the particular insurance taken, the legal and the financial risks are mainly decided by facts that neither the insurer nor the insured can influence.

To say something more general about the overall estimate that has to be done in weighing the interests of the insurer against those of the insured is not easy. Two important remarks however must be made. The first one is that the social character of insurance to a certain extent influences the whole issue. The second one is that particular consideration has to be given to the need for protection of an insured who in his capacity as consumer or otherwise has an inferior position in the contractual relationship. The imbalance may be of an economic as well as of a legal nature. If it is of an economic nature, the economic consequences are significantly abusive to the other party. If it is a legal imbalance, the term confers rights upon one party and not upon the other (mirror image rule).

\subsection{No black list}

In the Directive on Unfair Terms in Consumer Contracts there is an attachment with a list for the guidance of terms that can be considered to be unfair (a "grey" list). These terms might be brought to the fore also concerning insurance. The list is not exhaustive. Inversely a term in the list needs not always to be unfair. Typically, however, this is the case. One can therefore presume that the term is unfair. In the national legislation there are two variants about how to treat this list as far as the national legislator is concerned. Most countries have brought the list directly into the law text. Others (like Denmark, Finland and Sweden) have instead preferred to do it by the aid of an "explanatory text". The latter model has been approved by the Court of Justice of the European Communities (see European Court reports 2002 Page I-04147) but only on the condition that the member states choose a form and method of implementation that offer a sufficient guarantee that the public can obtain knowledge of the list.

Like Article 4:110 PECL, Art. 2: 304 PEICL contains no list of clauses deemed to be unfair. For the subject of insurance contracts, a listing of contract terms being per se unfair would be nearly impossible because of the large variety of types of insurance contracts that would have to be taken into account. This does not mean that the list in the Annex to the EC Directive can not be taken into consideration for deciding if a clause is unfair. But it has to be taken into account, that the list is indicative rather than conclusive and that of the terms on the list only a few concern insurance contracts. The Annex to the EC Directive mentions the following clauses:

"1. Terms which have the object or effect of:

(a) excluding or limiting the legal liability of a seller or supplier in the event of the death of a consumer or personal injury to the latter resulting from an act or omission of that seller or supplier; 
(b) inappropriately excluding or limiting the legal rights of the consumer visà-vis the seller or supplier or another party in the event of total or partial nonperformance or inadequate performance by the seller or supplier of any of the contractual obligations, including the option of offsetting a debt owed to the seller or supplier against any claim which the consumer may have against him;

(c) making an agreement binding on the consumer whereas provision of services by the seller or supplier is subject to a condition whose realization depends on his own will alone;

(d) permitting the seller or supplier to retain sums paid by the consumer where the latter decides not to conclude or perform the contract, without providing for the consumer to receive compensation of an equivalent amount from the seller or supplier where the latter is the party cancelling the contract;

(e) requiring any consumer who fails to fulfil his obligation to pay a disproportionately high sum in compensation;

(f) authorizing the seller or supplier to dissolve the contract on a discretionary basis where the same facility is not granted to the consumer, or permitting the seller or supplier to retain the sums paid for services not yet supplied by him where it is the seller or supplier himself who dissolves the contract;

(g) enabling the seller or supplier to terminate a contract of indeterminate duration without reasonable notice except where there are serious grounds for doing so;

(h) automatically extending a contract of fixed duration where the consumer does not indicate otherwise, when the deadline fixed for the consumer to express this desire not to extend the contract is unreasonably early;

(i) irrevocably binding the consumer to terms with which he had no real opportunity of becoming acquainted before the conclusion of the contract;

(j) enabling the seller or supplier to alter the terms of the contract unilaterally without a valid reason which is specified in the contract;

(k) enabling the seller or supplier to alter unilaterally without a valid reason any characteristics of the product or service to be provided;

(1) providing for the price of goods to be determined at the time of delivery or allowing a seller of goods or supplier of services to increase their price without in both cases giving the consumer the corresponding right to cancel the contract if the final price is too high in relation to the price agreed when the contract was concluded;

(m) giving the seller or supplier the right to determine whether the goods or services supplied are in conformity with the contract, or giving him the exclusive right to interpret any term of the contract;

(n) limiting the seller's or supplier's obligation to respect commitments undertaken by his agents or making his commitments subject to compliance with a particular formality;

(o) obliging the consumer to fulfil all his obligations where the seller or supplier does not perform his;

(p) giving the seller or supplier the possibility of transferring his rights and obligations under the contract, where this may serve to reduce the guarantees for the consumer, without the latter's agreement; 
(q) excluding or hindering the consumer's right to take legal action or exercise any other legal remedy, particularly by requiring the consumer to take disputes exclusively to arbitration not covered by legal provisions, unduly restricting the evidence available to him or imposing on him a burden of proof which, according to the applicable law, should lie with another party to the contract.

2. Scope of subparagraphs (g), (j) and (l)

(a) Subparagraph ( $\mathrm{g}$ ) is without hindrance to terms by which a supplier of financial services reserves the right to terminate unilaterally a contract of indeterminate duration without notice where there is a valid reason, provided that the supplier is required to inform the other contracting party or parties thereof immediately.

(b) Subparagraph (j) is without hindrance to terms under which a supplier of financial services reserves the right to alter the rate of interest payable by the consumer or due to the latter, or the amount of other charges for financial services without notice where there is a valid reason, provided that the supplier is required to inform the other contracting party or parties thereof at the earliest opportunity and that the latter are free to dissolve the contract immediately.

Subparagraph ( $\mathrm{j}$ ) is also without hindrance to terms under which a seller or supplier reserves the right to alter unilaterally the conditions of a contract of indeterminate duration, provided that he is required to inform the consumer with reasonable notice and that the consumer is free to dissolve the contract.

(c) Subparagraphs (g), (j) and (1) do not apply to:

- transactions in transferable securities, financial instruments and other products or services where the price is linked to fluctuations in a stock exchange quotation or index or a financial market rate that the seller or supplier does not control;

- contracts for the purchase or sale of foreign currency, traveller's cheques or international money orders denominated in foreign currency;

(d) Subparagraph (l) is without hindrance to price-indexation clauses, where lawful, provided that the method by which prices vary is explicitly described."

For the matter of insurance contracts, only a few of these terms in the list above become relevant. These are namely ${ }^{2}$

(a) Terms that mislead the insured consumer about the contract:

(i) "Hidden terms": This is for example a term irrevocably binding the insured to terms with which the insured had no real opportunity of becoming acquainted before the conclusion of the contract (para $1 \mathrm{i}$ on the grey list). In this context "acquaintance" first of all requires intelligibility of the terms. The more complex they are, the less intelligible they become and the harder it will be for the insurer to prove that the insured had a real opportunity of understanding them. The practice of some insurance outlets like travel agencies selling travel insurance to offer scant summaries of cover will not be sufficient.

A "hidden term" can also be one that remits to a legal provision which is not quoted in the contractual terms.

2) The list of terms that concern insurance context as well as the examples given have been taken over with a few adaptions from Clarke [1], p. 19-48ff. 
Another example is important terms hidden in long documents, perhaps with small print ("unfair surprises").

(ii) "Entire agreement" clauses, some of which fall within the grey list category of terms "limiting the ... supplier's obligation to respect commitments undertaken by his agents" (para 1 on the grey list). For example: "All terms of the contract of insurance are contained in this policy. No representations are made or given by the Company save as appear herein." Otherwise the insured could not rely on what the selling agent had said about the policy terms. Besides that this category also includes terms saying that when completing the proposal, the insurer's agent is acting not on behalf of the insurer, as most proposers would (reasonably) expect, but on behalf of the applicant.

(b) Terms that excuse unproper performance of contractual obligations:

(i) Terms excluding liability for delay in handling and paying claims are terms "inappropriately excluding or limiting the legal rights of the consumer vis-a-vis the ... supplier ... in the event of total or partial non-performance or inadequate performance by ... the supplier of any of the contractual obligations" (para $1 \mathrm{~b}$ on the grey list).

(ii) Terms "obliging the insured to fulfil all his obligations where the insurer does not perform his" (para 1 o on the grey list).

(c) Terms erecting barriers to redress: These are terms "excluding or hindering the consumer's right to take legal action or exercise any other legal remedy" (para 1 q on the grey list), including:

(i) A term enabling the insurer to mount a technical defence. Such might be a term requiring notice of loss in an unduly short period of time.

(ii) A term requiring "proof satisfactory to the insurer", if it allows the insurer to make unfair demands on the claimant consumer.

(iii) A "reverse burden clause", whereby the insurer has merely to allege that the loss claimed is excepted rather than covered to put upon the claimant the burden of proving otherwise.

(iv) Arbitration clauses: the insured is required to take disputes exclusively to arbitration not covered by legal provisions. Such clauses are considered to be potentially unfair as the insured is likely to be no match for the insured in the arbitral process - any more than in a foreign court.

(v) Any other term the effect of which is to enable the insurer to be slow in paying a claim.

(d) Terms that allow the insurance supplier to cancel the contract, at least when the insured has no equivalent right (para $1 \mathrm{~g}$ on the grey list).

(i) Terms that have the effect of allowing the insurer to cancel the contract without reasonable notice except where there are serious grounds for doing so. Thus terms with a cancellation period that does not give the insured enough time to seek alternative cover.

(ii) Terms whereby insurers are entitled to cancel cover but to retain premium.

(e) Terms that allow the insurer to vary an insurance contract unilaterally without a valid reason specified in the contract (para $1 \mathrm{j}$ on the grey list). This includes terms that entitle the insurer to vary the premium unilaterally during the insurance period or to assign the contract to another insurer.

(f) Terms that allow disproportionate penalties for breach by the consumer (para $1 \mathrm{~d}$ and e on the grey list) 


\subsection{Sanctions}

Paragraph 3 of Art. 2: 304 deals with the sanctions of unfair terms. If a term is unfair, it does neither bind the policyholder nor the insured or the beneficiary, which do not have to be identical. This provision is meant to guarantee that none of the persons that would have to suffer under an unfair term can be forced to stick to it against his or her will. The consequence that an unfair term is not binding corresponds with the sanction provided in Art. 6. 1 of the Directive but it differs from the one provided in Art. 4:110 PECL where the consequence of the unfairness of the term is voidability. Giving the insured the possibility of avoiding the term would lay the decision, if the term will come or stay in effect into the hands of the insured who's decision could be influenced by the insurer. The fact that an unfair term is not binding by law protects the insured who will not be forced to decide if the term has to be avoided or not. As the insurer is bound even by a term that is unfair to the detriment of the insured, the fact, that an unfair term is not binding on the policyholder, the insured or the beneficiary will not lead to problems in practice, as the effected person still has got the possibility to stick to the term in agreement with the insurer who has got no possibility of fighting against a term that is to his advantage.

If a term is unfair, the remainder of the contract remains in force if this is possible and appropriate. Otherwise the term has to be replaced by a term that reasonable parties would have chosen instead of the unfair term. Therefore it has to be considered, what a reasonable insurer and a reasonable average policyholder would have agreed upon at the time of concluding the contract, if they had known about the unfairness of the term.

\subsection{Burden of proof: unfairness}

Paragraph 4 of Art. 2:304 lays the burden of proof that a term has been individually negotiated on the insurer.

The burden of proof regarding the significant imbalance in the parties 'rights and obligations lies with the insured. This is a rule corresponding to the normal way of handling the burden of proof in the national insurance contract laws. However, one is here only at the starting point. One cannot require the insured to prove why the setting of the premium is too high, since only the insurer knows how the operation has been done. So it must be the insurer who gives the closer information on this issue. Thus it is the insurer who has to prove the closer considerations behind the premium fixing. The calculation of the premium is a difficult question. Sweeping answers saying for instance that covering a risk that according to the insurer ought not to be covered would lead to an increase of premiums for the whole risk group in question, should not be accepted.

\section{References}

1. Clarke, M.: The law of insurance contracts, LLP Professional Publishing (2002) 